\title{
Upaya Meningkatkan Hasil Belajar Passing Dalam Permainan Bola Voli Melalui Model Ring Target Pada Siswa Kelas VII SMP Negeri 3 Sampoiniet
}

\author{
T. Safran, S.Pd \\ SMP Negeri 3 Sampoiniet
}

\begin{abstract}
Abstrak
Latar belakang penelitian ini yaitu hasil belajar passing dalam permainan bola voli di SMP Negeri 3 Sampoiniet masih rendah. Hal ini dapat dilihat dari persentase tingkat serapan siswa terhadap materi passing dalam permainan bola voli yang hanya $20 \%$. Permasalahan dalam penelitian ini adalah apakah ring target dapat membantu meningkatkan hasil belajar passing dalam permainan bola voli bagi siswa kelas SMP Negeri 3 Sampoiniet tahun pelajaran 2019/2020?. Tujuan penelitian ini adalah untuk meningkatkan hasil belajar passing dalam permainan bola voli melalui model ring target bagi siswa kelas SMP Negeri 3 Sampoiniet. Jenis penelitian ini adalah Penelitian Tindakan Kelas yang dilaksanakan dalam 2 siklus. Subjek penelitian ini adalah seluruh siswa kelas VII yang berjumlah 18 siswa. Teknik Pengumpulan data yang dilakukan adalah observasi, pemberian kuesioner, tes unjuk kerja serta dokumentasi berupa dokumen dan foto. Hasil penelitian menunjukkan bahwa pembelajaran passing dalam permainan bola voli melalui model ring target meningkat. Hal ini dilihat dari persentase ketuntasan belajar siswa dari semua aspek pada siklus I yaitu sebesar $44 \%$ meningkat pada siklus II menjadi $83 \%$ dan siklus III $100 \%$. Ketuntasan hasil belajar siswa pada setiap siklus rata-rata dari aspek kognitif, aspek afektif dan aspek psikomotor. Ketuntasan belajar aspek kognitif pada kegiatan awal yaitu sebesar $30 \%$, pada siklus sebesar I 77\% dan siklus II 92\% Ketuntasan belajar aspek afektif pada siklus I yaitu sebesar 69\%, siklus II sebesar 88\% dan siklus III 94\%.
\end{abstract}

Kata kunci : bola voli, passing, ring target.

\section{PENDAHULUAN}

Pendidikan jasmani olahraga dan kesehatan (PJOK) adalah kelompok pelajaran wajib yang ada dalam kurikulum pembelajaran pada tingkat satuan pendidikan Sekolah Dasar/sederajat. Mata pelajaran penjasorkes merupakan mata pelajaran yang mempunyai aspek luas, tidak hanya bertujuan untuk meningkatan aspek fisik saja, namun penjasorkes berusaha untuk meningkatkan pengetahuan, meningkatkan kemampuan sosial dengan melatih siswa bersifat jujur dan sportif, mengembangkan kerja sama, dan mengembangkan nilai-nilai ataupun sikap positif dalam dirinya. Pembelajaran pendidikan jasmani di sekolah mencakup beberapa cabang olahraga seperti atletik, senam, permainan, pengembangan, bela diri, olahraga air, aktifitas riftmik dan aktivitas luar kelas.

Passing adalah suatu pukulan melambungkan bola yang bertujuan untuk memberikan umpan kepada teman di lapangannya sendiri. Proses belajar mengajar mata pelajaran pendidikan jasmani kelas VII SMP Negeri 3 Sampoiniet diampu oleh seorang guru pendidikan jasmani olahraga dan kesehatan., dalam proses belajar mengajar permainan bola voli khususnya pembelajaran teknik dasar passing muncul permasalahan yang dihadapi oleh guru setelah penyampaian materi. 
Permasalahan yang dimaksud yaitu tingkat pemahaman masing-masing siswa setelah diberikan materi teknik passing dalam permainan bola voli muncul penyerapan yang berbeda-beda dalam prakteknya. Setelah diajarkan, siswa dalam melakukan teknik passing masih banyak yang salah. Seperti posisi kaki, sikap badan, perkenaan bola pada tangan dan arah bola setelah dilakukan passing oleh siswa tidak sesuai dengan tujuan yang diinginkan. Memang tetap bisa melaksanakan pembelajaran tetapi hasil belajarnya tidak sesuai dengan yang diharapkan oleh guru karena belum mencapai target.

Masalah yang paling mendasar yaitu tidak terarahnya passing saat menerima bola yang datang dari lawan. Hal ini disebabkan karena: 1. penguasaan teknik passing dalam permainan bola voli yang masih rendah. 2. tingkat penyerapan materi passing dalam permainan bola voli hanya $44 \%$. Hal ini didapat dari rata-rata ketuntasan pembelajaran passing dalam permainan bola voli tiap kelasnya hanya 8 siswa. Siswa Sekolah Dasar yang tidak membekali diri dengan ikut kegiatan tambahan seperti ekstrakurikuler ataupun ikut klub di luar sekolah dan hanya mengikuti pembelajaran pendidikan jasmani olahraga dan kesehatan di sekolah saja maka kemampuannya masih relatif di bawah dibandingkan dengan mereka yang ikut kegiatan ekstra di luar jam sekolah. Ditambah jam belajar yang dirasa masih kurang untuk lebih mengintensifkan suatu teknik dasar saja. Karena banyak materi dari cabang olahraga lain yang harus diajarkan oleh guru pendidikan jasmani olahraga dan kesehatan dalam kurun waktu satu semester sesuai dengan kurikulum yang berlaku.

Hal ini yang membuat hasil belajar terhadap siswa yang tidak mengikuti kegiatan tambahan di luar jam sekolah masih rendah. Dari hasil observasi dengan wawancara tersebut, siswa kelas VII SMP Negeri 3 Sampoiniet membutuhkan pembelajaran yang kreatif dan inovatif guna mengoptimalkan hasil belajarnya di sekolah. Ring target digunakan peneliti yang diharapkan mampu meningkatkan hasil belajar siswa karena merupakan model pembelajaran baru sehingga dapat memotivasi siswa Kelas VII SMP Negeri 3 Sampoiniet dalam mengikuti pembelajaran Penjasorkes. Berdasarkan hal tersebut, penulis tertarik untuk mengadakan penelitian tentang "Meningkatkan Hasil Belajar Passing dalam Permainan Bola Voli Melalui Model Ring Target bagi Siswa Kelas VII SMP Negeri 3 Sampoiniet Tahun Pelajaran 2019/2020.”

\section{Tujuan Penelitian}

Tujuan dari penelitian ini adalah untuk meningkatkan hasil belajar passing dalam permainan bola voli melalui model ring target bagi siswa kelas VII SMP Negeri 3 Sampoiniet.

\section{KAJIAN PUSTAKA \\ Belajar Gerak}

Belajar gerak merupakan studi tentang proses keterlibatan dalam memperoleh dan menyempurnakan keterampilan gerak (motor skills). Sebab keterampilan gerak sangat terikat dengan latihan dan pengalaman individu yang bersangkutan. Belajar gerak khusus dipengaruhi oleh berbagai bentuk latihan, pengalaman, atau situasi belajar pada gerak manusia (Amung Ma'mun dan Yudha M. Saputra, 2000:3).

\section{Pengertian Pembelajaran}

Pengertian Pembelajaran Gagne (dalam Achmad Rifa'i RC dan Chatarina Tri Anni, 2010:192) menyatakan bahwa pembelajaran merupakan serangkaian peristiwa eksternal peserta didik yang dirancang untuk mendukung proses internal belajar. 
Menurut Briggs (dalam Achmad Rifa'i RC dan Chatarina Tri Anni, 2010:193) menjelaskan bahwa pembelajaran adalah seperangkat peristiwa yang mempengaruhi peserta didik sedemikian rupa sehingga peserta didik itu memperoleh kemudahan dalam berinteraksi berikutnya dengan lingkungan. Pengertian pembelajaran adalah usaha pendidik membentuk tingkah laku yang diinginkan dengan menyediakan lingkungan, agar terjadi hubungan stimulus (lingkungan) dengan tingkah laku peserta didik ( Achmad Rifa'i RC dan Chatarina Tri Anni, 2010:192).

\section{Pembelajaran}

Pembelajaran merupakan proses komunikasi antara pendidik dengan peserta didik atau antar peserta didik. Dari beberapa penjelasan di atas dapat disimpulkan pengertian pembelajaran yaitu serangkaian usaha yang dilakukan pendidik untuk membentuk tingkah laku peserta didik dengan melibatkan faktor eksternal seperti lingkungan belajarnya.

\section{Pengertian Pendidikan Jasmani}

Pengertian Pendidikan Jasmani Menurut Siedentop dalam Husdarta (2010:142) menyatakan bahwa pendidikan jasmani merupakan bagian integral dari keseluruhan proses pendidikan. Artinya pendidikan jasmani menjadi salah satu media untuk membantu ketercapaian tujuan pendidikan secara keseluruhan yang diharapkan dapat berkontribusi positif terhadap peningkatan pembangunan manusia. Menurut Achmad Paturusi (2012:1)

\section{Konsep Bermain}

Menurut Johan Huizinga dalam Husdarta (2010:130), memaparkan karakteristik bermain sebagai aktifitas yang dilakukan secara bebas dan sukarela. Berbeda dengan motif bermain pada anak yang dilakukan karena merupakan dorongan naluri yang berguna untuk merangsang perkembangan fisik dan mentalnya, pada orang dewasa, bermain dilakukan sebagai kebutuhan, tanpa paksaan dan dilaksanakan karena orang mau melaksanakannya. Menurut Sukintaka (1992:7) bermain merupakan aktifitas yang dilakukan dengan suka rela atas dasar rasa senang. Bermain dengan rasa senang menumbuhkan aktivitas yang dilakukan secara spontan.

\section{METODE PENELITIAN}

\section{Subjek Penelitian}

Subjek dalam penelitian ini adalah guru pendidikan jasmani olahraga dan kesehatan Kelas VII SMP Negeri 3 Sampoiniet.

\section{Objek Penelitian}

Objek dalam peneltian ini adalah siswa kelas VII SMP Negeri 3 Sampoiniet tahun pelajaran 2019/2020 yang berjumlah 18 siswa terdiri dari 8 laki-laki dan 10 perempuan.

\section{Tempat dan Waktu Penelitian}

Penelitian ini dilaksanakan di SMP Negeri 3 Sampoiniet pada kelas VII tahun pelajaran 2019/2020. Penelitian dilaksanakan 2 siklus dengan mengaplikasikan pembelajaran dengan pokok masalah bagaimana meningkatkan hasil belajar passing dalam permainan voli melalui model ring target. 
Penelitian Tindakan Kelas (PTK) ini dilaksanakan pada tanggal 09 sampai dengan 24 Februari 2019. Dalam 1 minggu dilaksanakan 1 kali pertemuan sesuai dengan jadwal mata pelajaran penjasorkes.

\section{Teknik Pengumpulan Data}

Dalam penelitian ini teknik yang digunakan peneliti untuk mengumpulkan data yaitu observasi (pengamatan), pemberian kuesioner, tes, dokumentasi

\section{Instrumen Pengumpulan Data}

Instrumen pengumpulan data adalah alat bantu yang dipilih dan digunakan oleh peneliti dalam kegiatannya mengumpulkan agar kegiatan tersebut menjadi sistematis dan dipermudah olehnya. Berdasarkan definisi tersebut suatu instrumen berfungsi untuk menjaring data-data hasil penelitian (Trianto, 2012:54). Instrumen pengumpulan data yang digunakan adalah Silabus, Rencana Pelaksanaan Pembelajaran (RPP), Lembar Observasi.

\section{HASIL PENELITIAN DAN PEMBAHASAN \\ Proses Pembelajaran}

Berdasarkan kondisi pembelajaran sebelum dilakukan dan sesudah dilakukan tindakan dengan menggunakan media sebagai alat bantu terjadi peningkatan terlihat dari semangat siswa dalam mengikuti pelajaran. Berbagai bentuk media yang membuat siswa yakin dalam kegiatan saat itu. Guru menjelaskan dengan baik sehingga siswa dapat melakukan yang sesuai dengan petunjuk dan materi pembelajaran.

\section{Diskripsi Pelaksanaan Kegiatan Awal (Pratindakan)}

Menurut kondisi yang didapatkan di lapangan bahwa siswa kelas VII SMP Negeri 3 Sampoiniet Kecamatan Sampoiniet Kabupaten Aceh Jaya mengalami hasil nilai yang diperoleh siswa kurang memuaskan belum sepenuhnya dapat menguasai materi pembelajaran Pendidikan Jasmani dan Kesehatan, dimana banyak siswa kelihatan tidak aktif dan kreatif dalam melakukan passing tersebut. Sebagai indikator bagi tercapainya suatu tujuan pembelajaran, peneliti menetapkan standar ketuntasan materi yaitu nilai 7,0 atau 70\% baik secara individu maupun secara klasikal.

Sebagai samper berikut ini peneliti sampaikan hasil belajar yang masing-masing terdiri dari 2 siklus yang terdiri dari siklus 1 sebagai perbaikan kegiatan awal dan siklus 2 sebagai perbaikan siklus 1 yang telah peneliti lakukan.

\section{Siklus Awal (Tanggal 09 Februari 2019)}

Dalam pelaksanaan siklus pertama peneliti menguraikan yaitu sebagai berikut :

a. Perencanaan (planning)

Dalam tahap ini peneliti dan guru mata pelajaran menyusun skenario pembelajaran yang terdiri dari :

1. Menyusun Rencana Program Pembelajaran (RPP) dengan materi passing dalam permainan bola voli

2. Menyusun instrumen tes passing dalam permainan bola voli

3. Menyusun lembar penilaian dan hasil pembelajaran

4. Menyusun lembar observasi

b. Tindakan (acting)

Pada tahap tindakan, kegiatan yang dilakukan adalah melaksanakan proses pembelajaran di lapangan dengan langkah-langkah kegiatan antara lain : 
1. Kegiatan awal

1) Siswa dibariskan dengan formasi 4 bersaf, setelah itu guru melakukan presensi.

2) Siswa melakukan pemanasan dan peregangan terlebih dahulu untuk mempersiapkan tubuh agar mengurangi resiko terjadinya cedera pada saat pembelajaran.

2. Kegiatan inti

1) Siswa berlatih melakukan passing dalam permainan bola voli melalui model ring target secara bergantian dengan pasangannya masingmasing.

2) Setelah semua sudah latihan siswa dikumpulkan kembali untuk diadakan tes passing dalam permainan bola voli melalui model ring target dengan pasangannya masing-masing selama 1 menit.

3) Kemudian setelah semua melakukan tes passing dalam permainan bola voli melalui model ring target, siswa dikumpulkan untuk mengerjakan soal pengetahuan yang diberikan oleh guru.

3. Kegiatan Penutup

Dalam kegiatan penutup guru memberikan refleksi dengan hasil pembelajaran yang telah dilakukan dalam kegiatan awal, memberikan apresiasi kepada siswa yang memperoleh hasil dengan baik, memotivasi siswa yang belum maksimal dalam pembelajaran pada kegiatan awal, kemudian membuat simpulan pembelajaran.

Pada akhir pelajaran siswa diberikan Apersepsi, Pre test, memberikan penjelasan serta memberikan acuan terhadap pembelajaran untuk hari ini dilanjutkan pembentukan kelompok diskusi yang tediri dari empat orang untuk setiap kelompok, menyelesaikan tugasnya masing dan melaporkan hasil kerjanya masing-masing kedepan kelas, ini dilakukan pada akhir pembelajaran di berikan evaluasi dalam RPP, dari analisis terhadap hasil belajar yang belum dicapai oleh siswa diperoleh data bahwa siswa yang memperoleh nilai 70 ke atas KKM 70 berjumlah 8 orang siswa dari keseluruhan 18 orang, maka jumlah siswa-siswi yang mengalami ketidaktuntasan atau belum memperoleh nilai menurut tuntutan KKM 10 orang.

Tabel Hasil belajar siswa kegiatan awal

\begin{tabular}{|c|c|c|c|c|}
\hline \multirow{3}{*}{ Awal } & \multicolumn{2}{|c|}{ Peroleh hasil belajar (KKM 70 \%) } & \multicolumn{2}{c|}{ Ketuntasan (\%) } \\
\cline { 2 - 5 } & Nilai 70 ke atas & Nilai 70 ke bawah & Tuntas & Tidak tuntas \\
\cline { 2 - 5 } & 8 Orang & 10 Orang & $44 \%$ & $56 \%$ \\
\hline
\end{tabular}

Pada awal pembejaran terlihat pada siswa. Dalam mengawali pelajaran yang baik tentunya ada motivasi yang diberikan para guru saat membuka pelajaran. Membuat siswa terbawa suasana belajar apalagi guru dalam menjelaskan pembelajaran tentang passing, sertai dengan membaca dan media pembelajaran sehingga timbullah minat belajar siswa dengan metode pembelajaran yang dibawakan. 


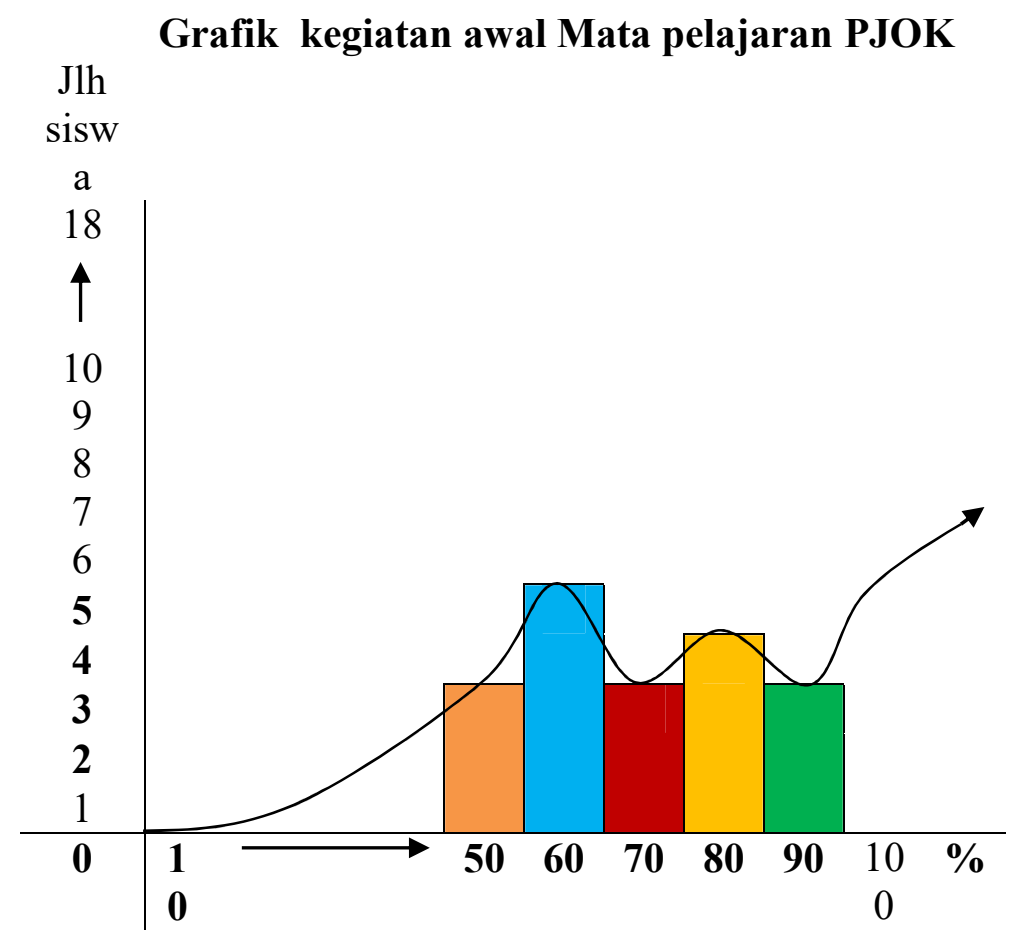

Grafik Persentase Siklus Awal

\section{Deskripsi Pelaksanaan Siklus I (Satu)}

Pertemuan ke II Pogram Perbaikan kegiatan awal Tanggal : 17 Februari 2019

Setelah dilakukan tahap pertama sebagai tahap awal, pada tahap ke dua ini meruapakan pogram perbaikan pada siklus kedua dengan uraian sebagai berikut :

1. Perencanaan (planning)

Dalam tahap ini peneliti dan guru mata pelajaran menyusun skenario pembelajaran yang terdiri dari :

1). Menyusun Rencana Program Pembelajaran (RPP) dengan materi passing dalam permainan bola voli

2). Menyusun instrumen tes passing dalam permainan bola voli

3). Menyusun lembar penilaian dan hasil pembelajaran

4). Menyusun lembar observasi

5). Menyiapkan media tambahan yang diperlukan untuk membantu pembelajaran

6). Menyiapkan tempat penelitian dan alat pembelajaran.

2. Tindakan (acting)

Pada tahap tindakan, kegiatan yang dilakukan adalah melaksanakan proses pembelajaran di lapangan dengan langkah-langkah kegiatan antara lain :

1. Kegiatan awal

1) Siswa dibariskan dengan formasi 4 bersaf, setelah itu guru melakukan presensi.

2) Siswa melakukan pemanasan dan peregangan terlebih dahulu untuk mempersiapkan tubuh agar mengurangi resiko terjadinya cedera pada saat pembelajaran.

2. Kegiatan inti

1) Siswa berlatih melakukan passing dalam permainan bola voli melalui model ring target secara bergantian dengan pasangannya masingmasing. 
2) Setelah semua sudah latihan siswa dikumpulkan kembali untuk diadakan tes passing dalam permainan bola voli melalui model ring target dengan pasangannya masing-masing selama 1 menit.

3) Kemudian setelah semua melakukan tes passing dalam permainan bola voli melalui model ring target, siswa dikumpulkan untuk mengerjakan soal pengetahuan yang diberikan oleh guru.

3. Kegiatan Penutup

Dalam kegiatan penutup guru memberikan refleksi dengan hasil pembelajaran yang telah dilakukan dalam siklus I, memberikan apresiasi kepada siswa yang memperoleh hasil dengan baik, memotivasi siswa yang belum maksimal dalam pembelajaran pada siklus I, kemudian membuat simpulan pembelajaran.

Tabel Hasil belajar siswa siklus I

\begin{tabular}{|c|c|c|c|c|}
\hline \multirow{3}{*}{$\begin{array}{c}\text { Siklus } \\
\text { I }\end{array}$} & \multicolumn{2}{|c|}{ Peroleh hasil belajar (KKM 70) } & \multicolumn{2}{c|}{ Ketuntasan (\%) } \\
\cline { 2 - 5 } & Nilai 70 ke atas & Nilai 70 ke bawah & Tuntas & Tidak tuntas \\
\cline { 2 - 5 } & 15 Orang & 3 Orang & $83 \%$ & $17 \%$ \\
\hline
\end{tabular}

3. Observasi

Observasi dilaksanakan pada tanggal 17 Februari 2019 aktivitas yang diamati sama dengan siklus I yaitu :

- Mengajukan pertanyaan.

- Menjawab pertanyaan siswa maupun guru

- Memberi saran.

- Menyelesaikan tugas kelompok

- Mempersentasikan hasil kerja kelompok.

Dari tabel diatas terlihat sudah terjadi perubahan yang cukup berarti, skor nilai yang diperoleh siswa. Pada analisa soal siklus II sudah mencapai $88 \%$ nilai rata-rata dari 18 orang siswa yang mampu mandapat nilai 70 keatas dan untuk dibidang aktivitas belajar siswa mencapai nilai $77 \%$ serta dalam hasil belajar siswa mencapai ketuntusan $83 \%$ kalau dibandingkan dalam pada siklus I sangat rendah hanya mencapai $50 \%$. Hal itu karena guru belum menggunakan metode pembelajaran yang sesuai pada kegiatan awal, sedangkan di siklus I ini guru telah melaksanakan pembelajaran yang sesuai dan menggunakan model ring target, siswa akan terarah dan dapat menemukan sendiri pengetahuan yang bermakna dan tak terlupakan.

Hal ini dapat dibuktikan dengan melihat daftar distribusi frekuensi. Tabel sebagai berikut :

Tabel Pengelolaan Data Lembaran Observasi Aktivitas Belajar Siswa Siklus I

\begin{tabular}{|c|c|c|c|}
\hline \multirow{2}{*}{ No } & \multirow{2}{*}{ Aktivitas Yang Diamati } & Jumlah Siswa & \multirow{2}{*}{ Keterangan } \\
\hline & & Pertemuan I & \\
\hline 1 & Mengajukan pertanyaan & 15 & $83 \%$ \\
\hline 2 & $\begin{array}{l}\text { Menjawab pertanyaan siswa maupun } \\
\text { guru }\end{array}$ & 18 & $100 \%$ \\
\hline 3 & Memberi saran & 12 & $67 \%$ \\
\hline 4 & Mengumukakan pendapat & 14 & $78 \%$ \\
\hline 5 & Mengajukan pertanyaan kelompok & 15 & $83 \%$ \\
\hline 6 & Mempresentasikan hasil kerja kelompok & 9 & $50 \%$ \\
\hline \multicolumn{3}{|c|}{ Rata-rata aktifitas siswa \% } & $77 \%$ \\
\hline
\end{tabular}


4. Refleksi.

Berdasarkan kumpulan data yang diperoleh dari koloborosi dengan teman sejawat serta catatan lapangan yang ada ternyata penelitian sebagian besar siswa belum mampu menyelesaikan tugas dengan optimal. Setelah pembelajaran selesai, hal itu terbukti dengan munculnya permasalahan diakhir pertemuan awal dan siklus I terlihat.

Grafik Siklus I Mata pelajaran PJOK



Grafik Persentase Siklus I

\section{DESKRIPSI PELAKSANAAN SIKLUS II}

\section{Pertemuan ke III Pogram Perbaikan Siklus II Tanggal : 24 Februari 2019}

Dalam pogram ini pelaksanaan tidak jauh berbeda dari siklus-siklus sebelumnya, dimana dalam pertemuan ini mengoptimalkan semua hal-hal yang telah dilakukan dan pogram perbaikan yang dilakukan dalam siklus ini. Untuk rincian kegiatan dalam siklus ini yaitu sebagai berikut :

1. Perencanaan (planning)

Dalam tahap ini peneliti dan guru mata pelajaran menyusun skenario pembelajaran yang terdiri dari :

1. Menyusun Rencana Program Pembelajaran (RPP) dengan materi passing dalam permainan bola voli

2. Menyusun instrumen tes passing dalam permainan bola voli

3. Menyusun lembar penilaian dan hasil pembelajaran

4. Menyusun lembar observasi

5. Menyiapkan media tambahan yang diperlukan untuk membantu pembelajaran

6. Menyiapkan tempat penelitian dan alat pembelajaran.

2. Tindakan (acting)

Pada tahap tindakan, kegiatan yang dilakukan adalah melaksanakan proses pembelajaran di lapangan dengan langkah-langkah kegiatan antara lain :

1. Kegiatan awal

1) Siswa dibariskan dengan formasi 4 bersaf, setelah itu guru melakukan presensi. 
2) Siswa melakukan pemanasan dan peregangan terlebih dahulu untuk mempersiapkan tubuh agar mengurangi resiko terjadinya cedera pada saat pembelajaran.

2. Kegiatan inti

1) Siswa berlatih melakukan passing dalam permainan bola voli melalui model ring target secara bergantian dengan pasangannya masing-masing.

2) Setelah semua sudah latihan siswa dikumpulkan kembali untuk diadakan tes passing dalam permainan bola voli melalui model ring target dengan pasangannya masing-masing selama 1 menit.

3) Kemudian setelah semua melakukan tes passing dalam permainan bola voli melalui model ring target, siswa dikumpulkan untuk mengerjakan soal pengetahuan yang diberikan oleh guru.

3. Kegiatan Penutup

Dalam kegiatan penutup guru memberikan refleksi dengan hasil pembelajaran yang telah dilakukan dalam siklus I, memberikan apresiasi kepada siswa yang memperoleh hasil dengan baik, memotivasi siswa yang belum maksimal dalam pembelajaran pada siklus I, kemudian membuat simpulan pembelajaran

Akivitas siswa dari siklus I (77\%) ke siklus II (93\%) di dalam menjawab soalsoal post-test di akhir pembelajaran. Pada siklus kedua siswa dapat menjawab soal-soal diakhir pembelajaran mencapai nilai rata-rata berbobot mencapai 16\%. Kemudian memberi penjelasan dan memotivasi dilengkapi dengan media pembelajaran dan bermain peran dalam permainan. Siswa sudah dapat menjawab pertanyaan rata-rata nilai berbobot adalah sebagai berikut :

Tabel Hasil belajar siswa siklus II

\begin{tabular}{|c|c|c|c|c|}
\hline \multirow{3}{*}{$\begin{array}{c}\text { Siklus } \\
\text { II }\end{array}$} & \multicolumn{2}{|c|}{ Peroleh hasil belajar (KKM 70) } & \multicolumn{2}{c|}{ Ketuntasan (\%) } \\
\cline { 2 - 5 } & Nilai 70 ke atas & Nilai 70 ke bawah & Tuntas & Tidak tuntas \\
\cline { 2 - 5 } & 18 Orang & 0 Orang & $100 \%$ & $0 \%$ \\
\hline
\end{tabular}

3. Observasi

Pengamatan observasi guru kolaborator mengamati hal-hal sebagai berikut dalam pembelajaran :

$>$ Guru peneliti menerapkan dan mempengaruhi keaktifan siswa

> Bimbingan guru peneliti terhadap siswa dalam melakukan diskusi kelompok terlihat mempengaruhi motivasi dan keaktifan siswa tetapi belum optimal.

Tabel Pengelolaan Data Lembaran Observasi Aktivitas Belajar Siswa Siklus II

\begin{tabular}{|c|c|c|c|}
\hline \multirow{3}{*}{ No } & \multirow{3}{*}{ Aktivitas Yang Diamati } & & \multirow{3}{*}{ Ket } \\
\hline & & Jumlah Siswa & \\
\hline & & Pertemuan II & \\
\hline 1 & Mengajukan pertanyaan & 18 & $100 \%$ \\
\hline 2 & Menjawab pertanyaan siswa maupun guru & 18 & $100 \%$ \\
\hline 3 & Memberi saran & 16 & $88 \%$ \\
\hline 4 & Mengumukakan pendapat & 14 & $78 \%$ \\
\hline 5 & Mengajukan pertanyaan kelompok & 18 & $100 \%$ \\
\hline 6 & Mempresentasikan hasil kerja kelompok & 17 & $94 \%$ \\
\hline \multicolumn{3}{|c|}{ Rata-rata aktifitas siswa \% } & $93 \%$ \\
\hline
\end{tabular}

Data hasil observasi terhadap aktivitas siswa terjadi peningkatan dari siklus ke I $77 \%$ dan ke silkus II $93 \%$, artinya terjadi Kenaikan persentase aktivitas siswa antara siklus I ke siklus II menjadi 16\%, ini disebabkan dengan adanya tindakan guru yang terus membimbing siswa secara individu ikut mempengaruhi kenaikan aktivitas 
tersebut. Dari data yang diperoleh masih ada siswa yang belum aktif telah dilakukan tindak lanjut memperpendekatan individu berulang-ulang.

4. Refleksi

Berdasarkan pengamatan guru kolaborator yang terlihat pada table kedua maka pelaksanaan tindakan direfleksikan sebagai berikut :

- Semua tindakan dapat berlangsung dengan baik

- Leaktifan siswa dalam kelompok tampak lebih aktif dan meningkat.

- Siswa lebih meningkat dalam menemukan konsep

- Hasil belajar siswa pada siklus II mencapai ketuntasan

- Pada kegiatan Pratindakan siswa dapat menjawab pertanyaan rata-rata $69 \%$

- Pada siklus I siswa dapat menjawab pertanyaan rata-rata $88 \%$

- Pada siklus II siswa dapat menjawab pertanyaan rata-rata $94 \%$

Berdasarkan hasil Post tes dari siklus I belum mencapai target ketuntasan belajar karena dianggap tuntas belajar apabila nilai dari hasil belajar 70\% dapat menjawab dengan baik. Pada siklus II ini nilai belajar siswa mencapai target ketuntasan, dalam hal ini guru peneliti di anggap berhasil membimbing siswa apabila sudah melebihi hasil KKM yang yang ditargetkan, hasil ketuntasan yang diperoleh di siklus II tenyata sudah mencapai target $100 \%$.

5. Evaluasi

Untuk mengetahui keberhasilan siswa secara klasikal pada akhir pembelajaran berlangsung di berikan tes akhir sebanyak sepuluh soal.

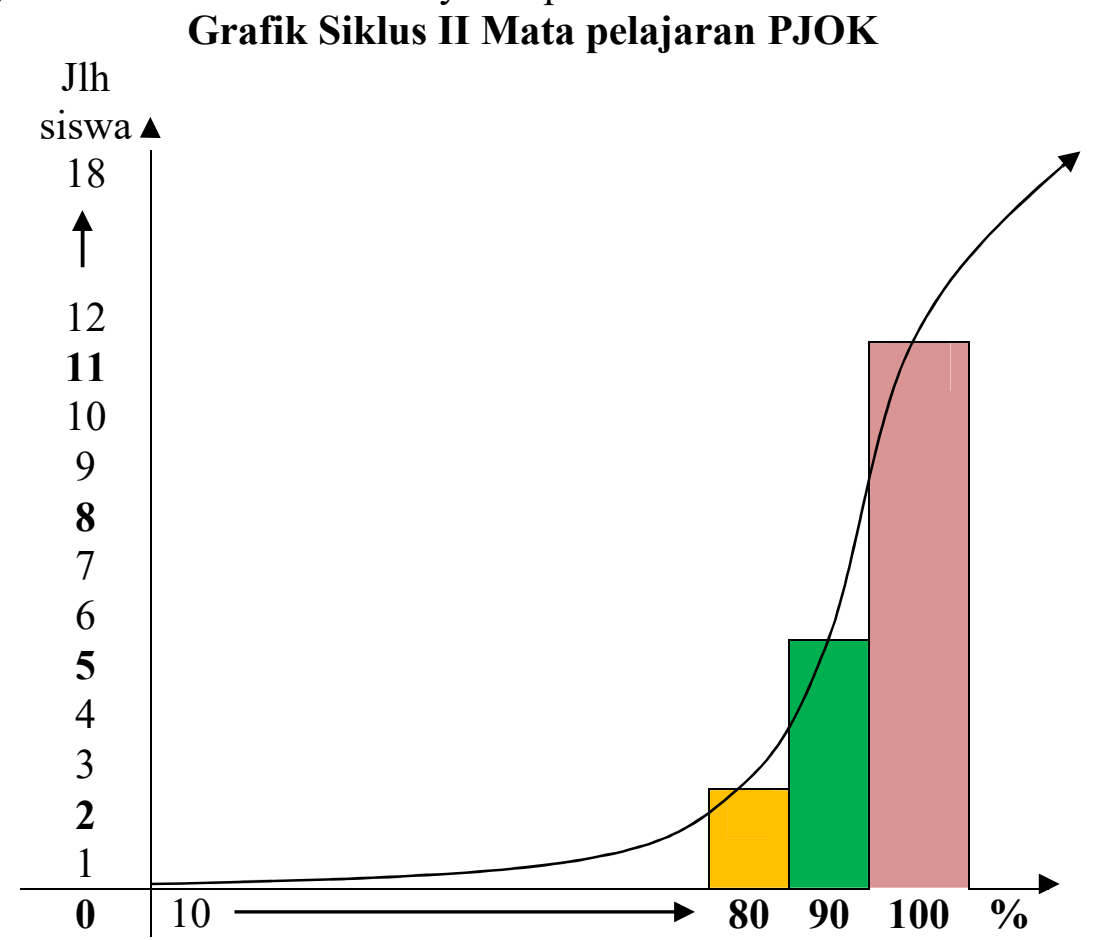

\section{Pembahasan Tiap Siklus dan Antar Siklus}

Berdasarkan hasil penelitian terdapat perbedaan prestasi belajar siswa antara siswa yang menggunakan media pembelajaran dengan metode ring target di SMP Negeri 3 Sampoiniet menunjukkan bahwa rata-rata berbobot yang diperoleh dengan rumus : 


$$
\begin{aligned}
& \sum F i X I \\
& \bar{X}=\frac{i=1}{\sum F i}
\end{aligned}
$$

Kegiatan Pra tindakan rata-rata $44 \%$

Siklus I rata-rata $83 \%$

Siklus II rata-rata $100 \%$

Untuk meningkatkan prestasi belajar siswa sangat ditentukan oleh berbagai faktor penunjang dalam proses belajar mengajar diantara faktor tersebut adalah penggunaan media pembelajaran dengan model ring target. Berdasarkan skor analisis soal setiap siklus dan lembaran observasi, catatan ternyata hasil yang diperoleh menunjukkan hasil yang berbeda antara prestasi hasil belajar siswa mengggunakan pembelajaran ring target dengan media pembelajaran sungguh jauh berbeda dengan tidak memakai alat peraga sama sekali..

Pada kegiatan pratindakan yang menjadi masalah dan kegagalan siswa dalam menjawab soal-soal yaitu konsep dasar masih terlalu umum solusinya adalah menjelaskan kembali konsep-komsep dasar dan langkah-langkah dalam dalam membaca. Pada siklus I (Pertama) kegiatan masih seperti pada siklus pertama tetapi ada penambahan kegiatan yang dilaksanakan oleh guru antara lain :

- Materi pembelajaran disesuaikan dengan teks.

- Mengisi lembaran kerja kelompok dan lembaran kerja siswa.

- Menyampaikan kesimpulan yang telah dirumuskan dalam kelompok masingmasing.

Pada siklus II (Kedua) siswa telah menjawab soal dengan baik dan benar, Untuk meningkatkan mutu pendidikan dalam proses belajar mengajar sekarang sangat memerlukan metode yang tepat. yaitu model ring target dengan menggunakan media pembelajaran untuk menciptakan belajar siswa aktif.

Penggunaan alat peraga dalam media pembelajaran sangat diperlukan yang menjadi siswa belajar segenap indranya dan pengalaman belajar lebih nyata dan tidak mudah terlupakan. Dengan demikian guru lebih mudah memberi bantuan kepada siswa yang belum mengerti semua upaya ini bermuara pada suatu tujuan yaitu usaha guru untuk meningkatkan prestsi belajar siswa.

Tabel Berikut ini data hasil belajar siswa per siklus

\begin{tabular}{|l|c|c|c|c|}
\hline \multirow{2}{*}{ Kegiatan } & \multicolumn{2}{|c|}{ Peroleh hasil belajar (KKM 70) } & \multicolumn{2}{c|}{ Ketuntasan (\%) } \\
\cline { 2 - 5 } & Nilai 70 ke Atas & Nilai 70 ke Bawah & Tuntas & Tak Tuntas \\
\hline Pra Tindakan & 8 Orang & 10 Orang & $44 \%$ & $56 \%$ \\
\hline Siklus I & 15 Orang & 3 Orang & $83 \%$ & $17 \%$ \\
\hline Siklus II & 18 Orang & - & $100 \%$ & $0 \%$ \\
\hline
\end{tabular}

Data ketuntasan hasil belajar siswa mulai dari kegiatan awal 44\% ke siklus I $83 \%$ terjadi peningkatan persentasi hingga menjadi $39 \%$ dan selanjutnya dari siklus I $83 \%$ ke siklus II $100 \%$ mengalami peningkatan hingga $17 \%$. artinya hasil belajar siswa dari awal sampai siklus II terjadi peningkatan yang sangat pesat menjadi $39 \%$. dan tentang data kemampuan PBM guru juga terjadi peningkatan katagori dari Kurang di kegiatan awal, baik di siklus I hingga Amat Baik di siklus II. 
Tabel Data aktivitas siswa antar siklus dapat dilihat pada tablel dibawah ini :

\begin{tabular}{|c|l|c|c|c|c|}
\hline \multirow{2}{*}{ No } & Aspek yang diamati & \multicolumn{2}{|c|}{ Siklus I } & \multicolumn{2}{c|}{ Siklus II } \\
\cline { 2 - 5 } & $\begin{array}{c}\text { Jlh } \\
\text { Siswa } \\
\text { aktif }\end{array}$ & $\%$ & $\begin{array}{c}\text { Jlh } \\
\text { Siswa } \\
\text { aktif }\end{array}$ & \% \\
\hline 1 & Mengajukan pertanyaan & 15 & $83 \%$ & 18 & $100 \%$ \\
\hline 2 & $\begin{array}{l}\text { Menjawab pertanyaan siswa maupun } \\
\text { guru }\end{array}$ & 18 & $100 \%$ & 18 & $100 \%$ \\
\hline 3 & Memberi saran & 12 & $67 \%$ & 16 & $88 \%$ \\
\hline 4 & Mengumukakan pendapat & 14 & $78 \%$ & 14 & $78 \%$ \\
\hline 5 & Mengajukan pertanyaan kelompok & 15 & $83 \%$ & 18 & $100 \%$ \\
\hline 6 & $\begin{array}{l}\text { Mempresentasikan hasil kerja } \\
\text { kelompok }\end{array}$ & 9 & $50 \%$ & 17 & $94 \%$ \\
\hline \multicolumn{2}{|c|}{ Rata-rata siswa aktif (\%) } & $\mathbf{7 7 \%}$ & & $\mathbf{9 3 \%}$ \\
\hline
\end{tabular}

Persentase kemampuan guru dalam melaksanakan PBM pada kegiatan awal juga terjadi peningkatan kemampuan guru dalam mengolah PBM dengan katagori cukup dan pada siklus I dengan katagori baik serta pada siklus II dengan katagori cukup baik. Data kemampuan guru pada saat melaksanakan PBM antar siklus dapat dilihat pada table berikut ini.

Tabel Data kemampuan PBM guru antar siklus

\begin{tabular}{|c|l|c|c|}
\hline \multirow{2}{*}{ No } & \multicolumn{1}{|c|}{ Aspek yang diamati } & \multicolumn{2}{|c|}{ Katagori/Siklus } \\
\cline { 2 - 4 } & \multicolumn{1}{|c|}{ I } & II \\
\hline 1 & Guru menyampaikan tujuan pembelajaran & Baik & Amat Baik \\
\hline 2 & $\begin{array}{l}\text { Guru memotivasi siswa untuk mengikuti } \\
\text { pelajaran dengan baik }\end{array}$ & Cukup & Baik \\
\hline 3 & $\begin{array}{l}\text { Guru mengelola PBM dengan } \\
\text { menggunakan media belajar }\end{array}$ & Baik & Amat Baik \\
\hline 4 & $\begin{array}{l}\text { Guru membimbing siswa menulis secara } \\
\text { individu }\end{array}$ & Baik & Amat Baik \\
\hline 5 & $\begin{array}{l}\text { Guru membimbing siswa membaca dengan } \\
\text { benar }\end{array}$ & Baik & Amat Baik \\
\hline 6 & $\begin{array}{l}\text { Guru memberikan penjelasan akhir dan } \\
\text { penguatan }\end{array}$ & Cukup & Baik \\
\hline 7 & $\begin{array}{l}\text { Guru melakukan penilaian } \\
\text { Rata-rata Katagori }\end{array}$ & Baik & AmatBaik \\
\hline
\end{tabular}

Berdasarkan dari seluruh hasil tindakan yang menunjukkan terjadi peningkatan hasil belajar siswa, peningkatan kreatif siswa serta meningkatkan terhadap kemampuan dalam melaksanakan proses belajar mengajar, maka dapat disimpulkan bahwa ring target merupakan sebagai media pembelajaran yang digunakan pada materi passing dalam pelajaran Pendidikan Jasmani dan Kesehatan khusus untuk kelas VII SMP Negeri 3 Sampoiniet.

\section{Kesimpulan}

Berdasarkan hasil penelitian dan pembahasan yang telah diuraikan, maka dapat disimpulkan pembelajaran melalui model ring target mampu meningkatkan hasil belajar passing dalam permainan bola voli bagi siswa kelas VII SMP Negeri 3 Sampoiniet tahun pelajaran 2019/2020. 
Peningkatan hasil belajar passing dalam permainan bola voli tersebut dapat dilihat dari tingkat ketuntasan nilai siswa pada kegiatan awal atau kata lain disebut pratindakan, siklus I dan silkus II. Pada awal persentase nilai ketuntasannya mencapai $44 \%$, siklus I mencapai $83 \%$ dan siklus II mencapai $100 \%$ dari nilai KKM yang ditentukan (70) Peningkatan hasil belajar passing dalam permainan bola voli melalui model ring target dari kegiatan awal hingga ke siklus II adalah sebesar 39\%.

\section{DAFTAR PUSTAKA}

Achmad Rifa'i dan Chatarina Tri Anni. 2010. Psikologi Pendidikan. Semarang : Unnes Press.

Amung Ma'mun dan Yudha M. Saputra. 2000. Perkembangan Gerak dan Belajar Gerak. Departemen Pendidikan dan Kebudayaan.

Husdarta, J.S. 2009. Manajemen Pendidikan Jasmani. Bandung: Alfabeta.

Husdarta. 2010. Sejarah dan Filsafat Olahraga. Bandung: Alfabeta

Suharsimi Arikunto. 2010. Prosedur Penelitian Suatu Pendekatan Praktik. Jakarta : Rineka Utama.

Sukintaka. 1992. Teori Bermain Untuk S1 PGSD Penjaskes. Departemen Pendidikan dan Kebudayaan.

Trianto. 2012. Panduan Lengkap Penelitian Tindakan Kelas Teori dan Praktek. Jakarta : Prestasi Pustakaraya. Undang-undang Republik 